The Emergence of Irish Gothic Fiction 



\section{The Emergence of Irish Gothic Fiction}

History, Origins, Theories

Jarlath Killeen 
(C) Jarlath Killeen 2014, under a Creative Commons Attribution-Non Commercial licence

Edinburgh University Press Ltd

22 George Square, Edinburgh EH8 9LF

www.euppublishing.com

Typeset in $10.5 / 13$ pt Sabon by Servis Filmsetting Ltd, Stockport, Cheshire, and printed and bound in Great Britain by CPI Group (UK) Ltd, Croydon CR0 4YY

A CIP record for this book is available from the British Library

ISBN 9780748690800 (hardback)

ISBN 9780748690817 (webready PDF)

The right of Jarlath Killeen

to be identified as author of this work

has been asserted in accordance with

the Copyright, Designs and Patents Act 1988. 